\title{
Phylogeny of Ten Kenyan Plectranthus Species in the Coleus Clade Inferred from Leaf Micromorphology, $\mathrm{Rbcl}$ and MatK Genes
}

\author{
Fredrick M. Musila, ${ }^{1}$ Catherine W. Lukhoba, ${ }^{2}$ Joseph M. Nguta, ${ }^{3}$ and Saifuddin F. Dossaji ${ }^{2}$ \\ ${ }^{1}$ Department of Applied and Technical Biology, School of Biological and Life Sciences, Technical University of Kenya, \\ P.O. Box 52428-00200, Nairobi, Kenya \\ ${ }^{2}$ School of Biological Sciences, College of Biological and Physical Sciences, University of Nairobi, P.O. Box 30197-00100, Nairobi, Kenya \\ ${ }^{3}$ Department of Public Health, Toxicology and Pharmacology, College of Agriculture and Veterinary Sciences, University of Nairobi, \\ P.O. Box 29053-00625, Nairobi, Kenya
}

Correspondence should be addressed to Fredrick M. Musila; musilamutie@gmail.com

Received 22 July 2017; Revised 31 October 2017; Accepted 20 November 2017; Published 18 December 2017

Academic Editor: Jutta Ludwig-Müller

Copyright (C) 2017 Fredrick M. Musila et al. This is an open access article distributed under the Creative Commons Attribution License, which permits unrestricted use, distribution, and reproduction in any medium, provided the original work is properly cited.

\begin{abstract}
Plectranthus species are difficult to taxonomically delimit due to lack of clear-cut morphological synapomorphies. This study is aimed at bringing insights into classification of ten Plectranthus species in the Coleus clade by using leaf micromorphology and molecular data. Stomatal counts and observation of microtome leaf sections generated leaf micromorphology data, while molecular data was obtained from sequencing $M a t K$ and $R b c l$ genes from each species. Phylogeny based on the $M a t K$ and $R b c l$ gene sequences clustered four species $P$. caninus, P. otostegioides, P. barbatus, and P. lanuginosus together (Clusters A and D, respectively), while $P$. pseudomarrubioides, $P$. ornatus, and P. aegyptiacus were grouped together into Clusters B and E, respectively, and $P$. montanus and P. amboinicus were grouped together (Cluster C). A dendrogram was generated through a cluster analysis of the leaf micromorphological characters grouped together, $P$. caninus, $P$. ornatus, $P$. otostegioides, $P$. montanus, and $P$. pseudomarrubioides (Cluster F). The dendrogram also grouped together P. aegyptiacus, $P$. amboinicus, $P$. edulis, $P$. barbatus, and P. lanuginosus (Cluster $\mathrm{G})$. The present study has grouped the ten studied Plectranthus species using molecular and leaf micromorphology characters into phylogenies, which are supported by previous studies, and proved that these characters can aid in plant identification and phylogenetic studies.
\end{abstract}

\section{Background and Justification}

Plectranthus belongs to the family Labiatae (Subfamily Nepetoideae, tribe Ocimeae). Plectranthus genus consists of about 300 species distributed in the tropical and warm regions of the world. Plectranthus species are aromatic, perennial subshrub, or succulent shrub ranging from $0.2 \mathrm{~m}$ to $5 \mathrm{~m}$ tall [1]. It has proved difficult to classify species within Plectranthus genus as there are no clear morphological synapomorphies and the genus is faced with a lot of synonymy whereby a species is referred by another name somewhere else [2]. In addition, several other closely related genera within Labiatae such as Ocimum L., Solenostemon Thonn., and Englerastrum Briq. are still treated separately and therefore Plectranthus in broad sense could be still paraphyletic [3]. Few taxonomic studies have been published on phylogenetic relationships among Plectranthus species. Initially, Plectranthus species were classified using morphological characters only and this led to placement of various species in different families like Verbenaceae rather than in their right Labiatae family [4]. In the latest revision of the genus based on morphological characters, two major clades are recognized within Plectranthus genus: Plectranthus and Coleus clades [5]. Plectranthus clade consists of about 30 species while Coleus clade consists of 70 species [5]. Coleus clade is further subdivided into three subclades by Paton et al. [5] which are Holostylon (species with an entire style), Solenostemon (species with fused anterior calyx lobes), and Calceolanthus (species whose calyx throat 
is surrounded by dense ring of hairs). Unlike Plectranthus clade, the most taxonomic difficulties are observed in the Coleus clade which is well-represented in Kenya and of which majority of the species are used as medicinal plants [2].

Paton et al. [4] proposed a new classification system using molecular data after he carried out a phylogeny of basils and allies (Labiatae, tribe Ocimeae) based on sequences of the trnL intron, $t r n L-t r n F$ intergenic spacer and $r p s 16$ intron. The study led to better understanding of the relationships among members of the tribe Ocimeae which includes Plectranthus genus and it was established that the tribe Ocimeae was monophyletic and easily diagnosable with morphological synapomorphies. Moreover, the study by Paton et al. [4] also indicated that Pycnostachys and Holostylon formed a monophyletic group which was closely related to Plectranthus genus. In another study, Lukhoba mapped Plectranthus economic uses to the phylogenetic tree based on molecular analysis proposed by Paton et al. [4] and concluded that species within the Coleus clade were richer in number and diversity of uses among the species of Plectranthus [2]. Elsewhere, Grayer carried out a chemosystematic study by looking at the distribution of exudate flavonoids in Plectranthus and found out that $40 \%$ of the species within the Plectranthus clade produced exudate flavonoids, mainly flavones, and that at least five species within the Plectranthus clade could produce flavanones while flavanols were only found in two species within the Coleus clade [3]. A phylogenetic study conducted on the medicinal plant $P$. asirensis J.R.I Wood, a plant endemic to Saud Arabia using rps16, rpoB, Rbcl, nrITS, and $r p o C 1$ genes, reported that $P$. asirensis was closely related to $P$. barbatus and $P$. hadiensis (Forssk.) Schweinf. Ex Spreng. and even more closely related to $P$. caninus and $P$. coeruleus based on DNA sequences from the nrITS and rpsi6 genes [6]. DNA from four species of Plectranthus, which include P. grandis, $P$. barbatus, $P$. neochilus, and P. amboinicus, was studied using RAPD analysis to show interspecific diversity among the four species by Bandeira et al. [7]. All the four species were shown to be monophyletic in origin with $P$. neochilus Schltr. being closely related to P. amboinicus while P. grandis (L.H.Cramer) R.H.Willemse was closely related to P. barbatus [7]. Moreover, a study on the development of barcodes for investigating phylogenetic relationships of $P$. hadiensis by Amarasinghe et al. [8] observed that $P$. hadiensis was closely related to $P$. amboinicus and P. amicorum S.T.Blake and even more closely related to both $P$. caninus and $P$. barbatus.

Leaf micromorphology may provide insights into how plant species evolve in terms of leaf anatomy and respond to different climatic conditions. Morphology of epidermal cells, stomata, and trichome types have been used as systematic characters and a combination of some of these features is relevant especially to the identification of species within the tribe Mentheae (subfamily Nepetoideae) in Labiatae family [9]. Several micromorphological studies have been conducted on Plectranthus and related genera. To begin with, comprehensive morphological studies of trichomes have been done on species of Lamiaceae family, notably the genus Salvia [10,11]. Ordinary caulinar secondary growth has been observed in many dicotyledons and has been reported in Plectranthus neochilus [12]. Rectangular transection is also frequently observed in members of Labiatae and also the presence of collenchyma in the four angles has also been observed in the family as well [13]. A quadrangular crosssection of the stem has been observed in P. barbatus and $P$. neochilus [14]. In P. barbatus stem, the endodermis has been reported to contain many amyloplasts and the vascular bundle arrangement of $P$. neochilus has a striking similarity with that of P. barbatus [14]. Such similarity has also been observed by Evert where the vascular bundles in Coleus are primarily formed in the fascicular regions [12].

With regard to leaf anatomy, members within the Labiatae family have diacytic and anomocytic stomata both on the abaxial and adaxial surfaces although tetracytic stomata have been observed in the family as well [14]. P. neochilus has been reported to have diacytic stomata (stomata surrounded by two cells) on both surfaces while P. barbatus has been reported to have anomocytic stomata where stomata are surrounded by many subsidiary cells [14]. In Plectranthus australis, diallelocytic stomata have been reported where three or more cells of different sizes at the right angles of the guard cells are found surrounding the stomata [15]. Micromorphological studies of trichomes of Lamiaceae revealed that different types of glandular and nonglandular trichomes occur in the family [16]. Glandular trichomes are responsible for the production of essential oils, flavone aglycones, and resiniferous acids which protect the plant from herbivores, pathogens as well as attracting insects for pollination. For example, peltate trichomes which have uniform morphology, capitate glandular, and nonglandular trichomes have been reported in the family [17]. Capitate trichomes have also been reported in P. madagascariensis (Pers.) Benth, P. ornatus and in P. barbatus [14]. Peltate trichomes of $P$. ornatus have been reported to be found only on the abaxial leaf surface while in P. madagascariensis they occur on both sides of the leaf [18].

With regard to organization of the leaf chlorenchyma, isobilateral, centric, or dorsiventral mesophyll has occasionally been reported in Lamiaceae family [16]. Dorsiventral mesophyll has been reported in P. barbatus while homogenous mesophyll occurs in P. neochilus [14]. In homogenous mesophyll, the leaf anatomy layers are very hard to differentiate and this kind of mesophyll is predominant in those species with succulent leaves [19]. Epidermal cell shapes in Plectranthus can either be polygonal, where they resemble polygons or sinuous, where they have many curved edges while midrib may be convex, concave, plain convex, biconvex, or concaveconvex [14].

Plectranthus still remains a controversial genus when it comes to classification and some species grouped under other genera could be still under Plectranthus. More studies are needed to investigate whether Plectranthus is monophyletic, to test the current generic circumscription and to determine morphological characters that are suitable to support a comprehensive phylogeny based classification. For example, studies on molecular phylogeny of Plectranthus using sequences from various regions of nucleus and chloroplast DNA such as trnK, nuclear ITS, Rbcl, and MatK or even using other methods such as SNPs (single nucleotide polymorphisms), RAPDS (random amplified polymorphic DNA), and RFLPs (restriction fragment length polymorphisms) need 
to be conducted. These molecular characters and methods may suggest relationships in phylogeny as they have been used successfully in other species [20-22]. Chemotaxonomic studies, leaf micromorphology, and cytology are also needed and may help in phylogenetic elucidation of Plectranthus genus. This will help in the development of a formal classification since the current groupings of Plectranthus species are not congruent with previous morphological classification of Plectranthus species [5]. The majority of species within Plectranthus genus is succulent leaves and stems and is aromatic due to glandular trichomes present on its leaves. Stems are quadrangular, leaves are simple, broad, and ovalshaped with a tapering tip and are very thick; they are thickly studded with hairs and the lower surface usually has numerous glandular hairs. Flowers are borne on a short stem, pale purplish in dense whorls at distant intervals in a long slender raceme [5]. Various diagnostic morphological characters described in the Flora of Tropical East Africa (FTEA) for identifying the ten species under investigation have been summarized in Table 1 .

\section{Materials and Methods}

2.1. Collection of Plectranthus Species Samples. Leaves and voucher specimens of ten Plectranthus species grouped under the Coleus clade were collected from various geographical regions of Kenya in 2014. Following information available in the Flora of Tropical East Africa on Plectranthus genus and also from already available nomenclatural types in the herbarium, it was possible to identify the specific locality of the species and collect them. Collected species were identified and voucher specimens deposited in Nairobi University Herbarium (NAI). The following are the voucher specimen numbers of the specimens collected: Plectranthus barbatus (FM2014/01), Plectranthus edulis (FM2014/02), Plectranthus ornatus (FM2014/03), Plectranthus caninus (FM2014/04), Plectranthus pseudomarrubioides (FM2014/05), Plectranthus otostegioides (FM2014/06), Plectranthus amboinicus (FM201407), Plectranthus aegyptiacus (FM2014/08), Plectranthus montanus (FM2014/09), and Plectranthus lanuginosus (FM2014/10).

2.2. DNA Extraction, PCR, and Sequencing. DNA was extracted from fresh leaves of the collected Plectranthus species using the cetyltrimethylammonium bromide (CTAB) DNA extraction method. Two chloroplast genes regarded as universal molecular markers suitable for phylogenetic studies for lower taxonomic ranks in plants were targeted. These genes were maturase $\mathrm{K}$ gene (MatK) and large subunit of the ribulose-bisphosphate carboxylase gene ( $R b c l)$. Amplification of DNA was carried out using primers of the two genes selected from previous phylogenetic studies of species within Labiatae. The primers were MatK-390F [23] and MatK-1326R [8] for amplifying the MatK gene and Rbcl-1F [24] and $R b c l 724 \mathrm{R}$ [25] for amplifying the $\mathrm{Rbcl}$ gene. The primers and synthetic oligonucleotides for DNA amplification were ordered from Inqaba Biotec East Africa (IBEA), South Africa. PCR products were purified and bidirectionally sequenced at Inqaba Biotec East Africa (IBEA). The obtained sequences of the two genes from the ten Plectranthus species were then exported to MEGA 6 software (Molecular Evolutionary Genetics Analysis Version 6) for phylogenetic analysis [26].

2.3. Phylogenetic Analysis. All the MatK and Rbcl sequences from the ten Plectranthus species were subjected to multiple alignment using muscle alignment method in MEGA6 [27]. Multiple sequence alignment helped identify gaps and similar and mismatch regions among the two molecular characters (MatK and $\mathrm{Rbcl}$ genes), which are prerequisite steps in the creation of phylogenetic trees. During phylogenetic analysis, the evolution model followed was maximum composite likelihood model [26] while the statistical method used was UPGMA (unweighted pair group method with arithmetic mean) [28] and the test for phylogeny was bootstrap method [29]. The number of bootstrap iterations for the sequences was set at 1000. The aligned sequences already in MEGA 6 were subjected to these three parameters resulting in construction of MatK and $\mathrm{Rbcl}$ maximum likelihood phylogenetic trees. Maximum composite likelihood is frequently preferred because it aids taxonomists to discriminate among many equally likely assignments by using the posterior probabilities for each probable nucleotide or amino acid assignment and to generate the most likely (most parsimonious) tree which fits the data [26].

\subsection{Stomatal Distribution and Density in Plectranthus Leaves.} One centimeter cubed of leaf tissue was removed from the middle section of the leaves of three individuals of each Plectranthus species and placed in a glass boiling tube. This was followed by addition of $5 \mathrm{ml}$ of glacial acetic acid and hydrogen peroxide in equal parts, in sufficient quantity to cover the material, and the tubes were then heated to $70^{\circ} \mathrm{C}$. After 2 hours, the epidermal layers were teased apart from each other, washed in water, stained and mounted on microscope slides, and observed at $\times 100$ and $\times 400$ magnifications [30]. Microscope type used was LEICA DM 500 microscope. Stomatal density was determined for each surface by counting stomata in magnification fields in the three individuals of each of the ten Plectranthus species investigated, then the average was calculated.

2.5. Leaf Micromorphology. To study leaf anatomy, portions of leaf lamina from three individuals of each species were cut into $4-10 \mathrm{~mm}^{2}$ sections prior to rehydration. Tissues were then rehydrated in a series of $25 \%$ alcohol, $10 \%$ alcohol, and distilled water followed by staining in saturated aqueous safranin $\mathrm{O}$. The stained tissues were then dehydrated in an alcohol series, $50 \%$ alcohol and $100 \%$ Xylene. The dehydrated tissues were then infiltrated in a series of xylene:paraffin oil (50\%:50\%) and 100\% paraffin oil followed by a second series of molten paraplast. The infiltrated tissues were later embedded in paraffin in casting boats. Paraffin embedded blocks were then sectioned transversely at $2 \mu \mathrm{m}$ thickness with razor blades on a rotary microtome [31]. Slides were later observed and photographed at $\times 100$ and $\times 400$ magnifications in LEICA DM 500 microscope to observe differences in the arrangement of various internal leaf layers (epidermal cells, 


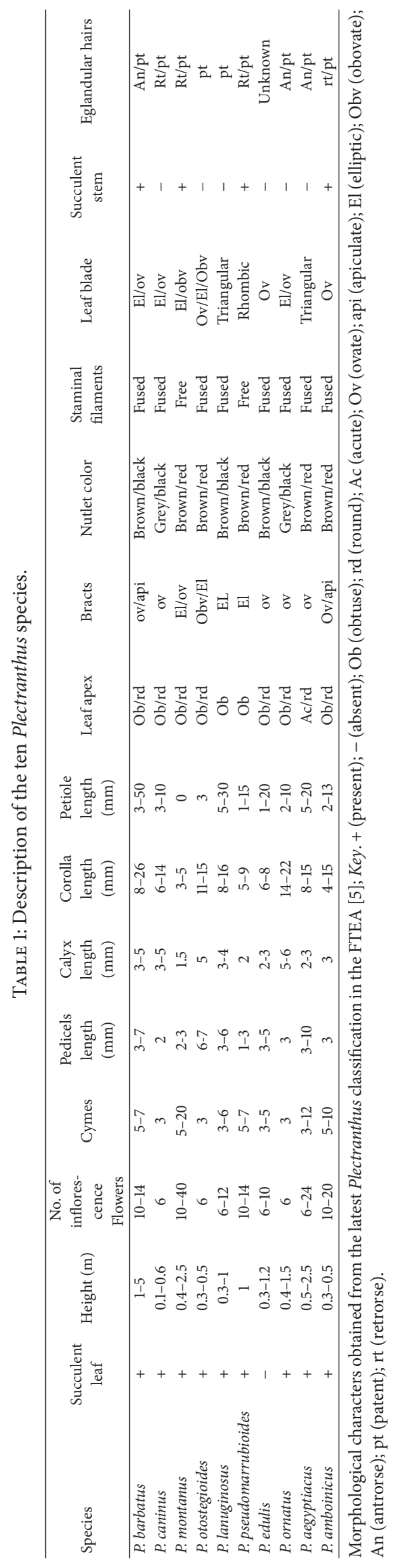


TABLE 2: GenBank accession numbers for genes from the ten Plectranthus species.

\begin{tabular}{|c|c|c|c|c|}
\hline Plectranthus species & Gene & GenBank accession number & Gene & GenBank accession number \\
\hline P. barbatus & MatK & MF495684 & $R b c l$ & MF495698 \\
\hline P. edulis & MatK & MF495685 & $R b c l$ & MF495696 \\
\hline P. montanus & MatK & MF495686 & $\mathrm{Rbcl}$ & MF495700 \\
\hline P. amboinicus & MatK & MF495687 & $R b c l$ & MF495701 \\
\hline P. lanuginosus & MatK & MF495688 & $R b c l$ & MF495699 \\
\hline P. otostegioides & MatK & MF495689 & $\mathrm{Rbcl}$ & MF495703 \\
\hline P. ornatus & MatK & MF495690 & $R b c l$ & MF495695 \\
\hline P. aegyptiacus & MatK & MF495691 & $R b c l$ & MF495702 \\
\hline P. caninus & MatK & MF495692 & $R b c l$ & MF495697 \\
\hline P. pseudomarrubioides & MatK & MF495693 & $\mathrm{Rbcl}$ & MF495694 \\
\hline
\end{tabular}

palisade layer, and spongy mesophyll) as well as trichomes among the Plectranthus species.

2.6. Cluster Analysis Based on LeafCharacters. Phenetic analysis (cluster and principal components) is commonly used as a tool to better understand the trends of morphological variations, by indicating relationships among taxa inform of dendrograms or cladograms [32]. Character states from the characters obtained in the study were assigned values and were subjected to hierarchical cluster analysis in SPSS Version 23 to generate a dendrogram showing linkages between the species based on their character values. The statistical method used was average linkage between groups which is also referred to as UPGMA [33]. This is the same statistical method used in the analysis of MatK and $\mathrm{Rbcl}$ sequences. Cluster analysis usually groups organisms together based on their overall similarity generating dendrograms. The dendrograms can be used to draw inferences about interspecific taxonomic relationships among the species investigated and can also be compared with molecular phylogenetic trees.

\section{Results and Discussion}

3.1. Molecular Phylogeny of Ten Plectranthus Species. After DNA sequencing, MatK and $\mathrm{Rbcl}$ genes from the ten Plectranthus species were deposited in the nucleotide database of GenBank. The assigned GenBank accession numbers (MF495684-MF495703) are presented in Table 2.

Aligned sequences were used in the creation of phylogenetic trees following maximum composite likelihood model and employing UPGMA and Bootstrap resampling as a statistical method and as a test of phylogeny, respectively. The most likely phylogenetic trees were constructed using gene sequences from the ten Plectranthus species as shown in Figure 1.

The numbers at branch nodes are bootstrap values which indicate percentage number of bootstrap iterations which support the tree at that particular point of divergence/at each node of the phylogenetic tree. The higher the bootstrap value, the more the topology of the phylogenetic tree is supported. Species close to each other in the phylogenetic tree are closely related. Based MatK gene sequences, $P$. caninus,
P. otostegioides, P. barbatus, and P. lanuginosus, have been shown to be closely related (Cluster A), this clade has a moderate bootstrap support value of 58, while $P$. ornatus, $P$. pseudomarrubioides, and $P$. aegyptiacus have been grouped together (Cluster B) and this grouping has a bootstrap value of 34 implying it is poorly supported. The phylogenetic tree also shows that $P$. montanus and $P$. amboinicus are closely related and form a monophyletic group (Cluster C) which has a moderate bootstrap support value of 52 . All the species share a distant common ancestor with $P$. edulis.

Based on the $R b c l$ gene sequences, $P$. pseudomarrubioides, P. montanous, P.ornatus, $P$. amboinicus, and $P$. edulis have also been grouped together (Cluster D), while $P$. caninus, $P$. lanuginosus, $P$. barbatus, and $P$. otostegioides have also been grouped together (Cluster E) and both groups are related to $P$. aegyptiacus which is grouped alone. Cluster $\mathrm{D}$ has a moderate bootstrap support value of 54, while Cluster E is well supported with a high bootstrap value of 87 .

Both $M a t K$ and $R b c l$ phylogenetic trees are strikingly similar. For example, based on the MatK genes, $P$. caninus, $P$. otostegioides, $P$. barbatus, and $P$. lanuginosus have been grouped together and all the four species form a monophyletic group (Cluster A). The same pattern can be observed in the phylogenetic tree created using the $R b c l$ genes (Cluster E). Again based on the MatK genes, $P$. pseudomarrubioides, $P$. ornatus, $P$. montanus, and $P$. amboinicus have been showed to be closely related (Cluster B). This close relationship of these species can also be observed in phylogenetic trees produced using the Rbcl genes (Cluster D). However, based on MatK genes, $P$. aegyptiacus has been shown to be closely related to $P$. pseudomarrubioides and $P$. ornatus (Cluster B), while based on the $R b c l$ genes, $P$. edulis is closely related to $P$. amboinicus, $P$. ornatus, $P$. pseudomarrubioides, $P$. amboinicus, and $P$. montanus (Cluster D).

\subsection{Leaf Micromorphology of Plectranthus Species}

3.2.1. Leaf Micromorphology of Plectranthus Species. Overall variations in leaf anatomical characters observed in three individuals of each of the ten Plectranthus species are tabulated in Table 3. The characters include nature of the leaf, stomata occurrence, stomata type, epidermal cell type, 


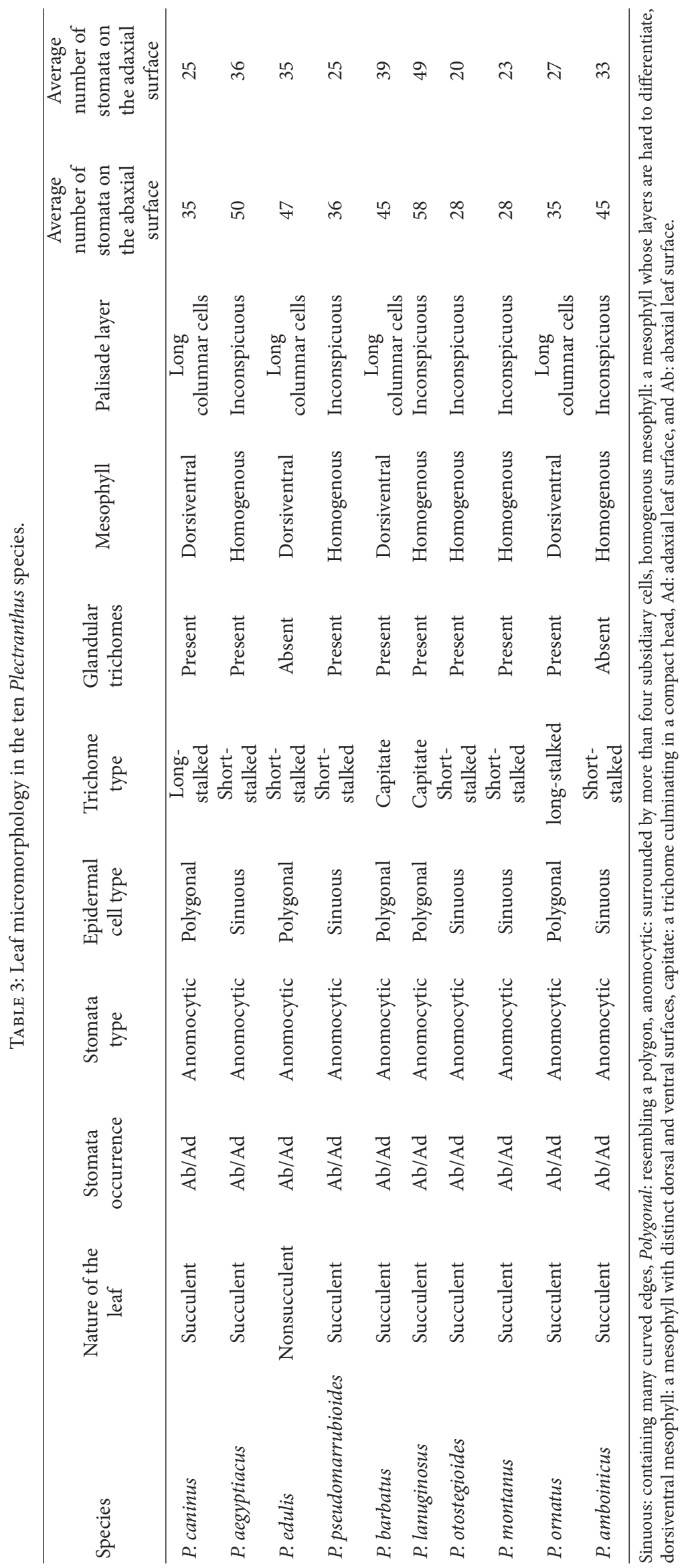




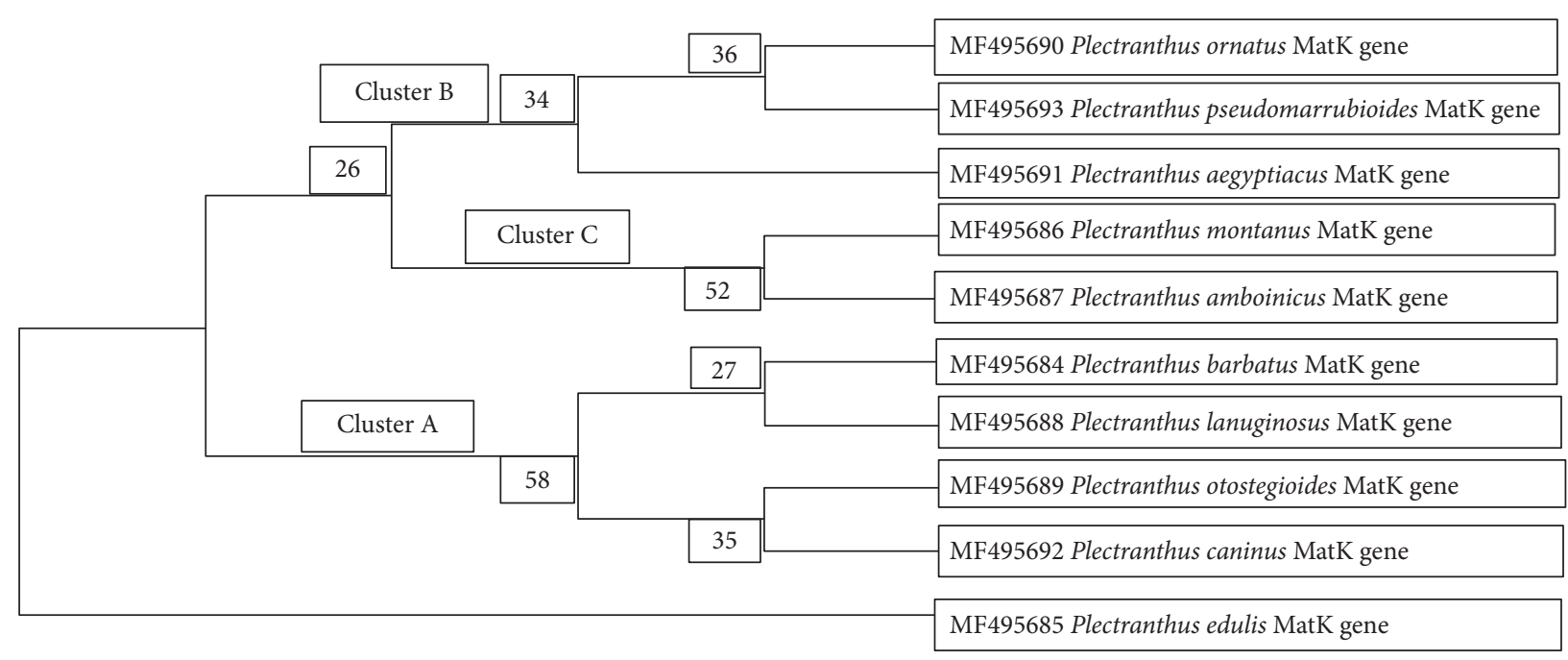

FIGURE 1: A bootstrap consensus phylogenetic tree based on MatK gene sequences.

trichome type, glandular trichomes, nature of the mesophyll, nature of the palisade layer, and the number of stomata on the adaxial and abaxial leaf surfaces.

Leaf anatomical characters which contributed to most of the differences among the ten Plectranthus investigated include epidermal cell type which was either sinuous (Figure 3) or polygonal (Figure 4), trichome type which ranged from being long-stalked, short-stalked, glandular, and nonglandular to capitate (Figure 5), nature of the leaf mesophyll which was either dorsiventral (whereby upper epidermis, palisade layer, spongy mesophyll, and lower epidermis were easily identified as distinct) or homogenous (whereby the various layers of the leaf mesophyll were indiscreet and not easily identified) (Figures 3 and 4). For the Plectranthus species with dorsiventral mesophyll, the palisade layer could easily be identified bearing the usual long columnar cells while for those with homogenous mesophyll, the palisade layer was inconspicuous just like the other layers of that homogenous mesophyll. The average number of stomata on both sides was highest in $P$. barbatus, $P$. amboinicus, $P$. aegyptiacus, $P$. lanuginosus, and $P$. edulis. Fewer numbers of stomata were observed in $P$. pseudomarrubioides, $P$. otostegioides, and $P$. montanus. In all the species, fewer numbers of stomata were observed in the adaxial surface compared to the abaxial surface (Table 3 ).

\subsubsection{Dendrogram Based on the Leaf Micromorphology Data.} Leaf micromorphology data was subjected to hierarchical cluster analysis. Character states were assigned values and scored in a matrix, the matrix (Table 4) was subjected to cluster analysis.

Hierarchical cluster analysis of the leaf micromorphology character state matrix in Table 4 in SPSS led to the average linkage dendrogram (Figure 6).

$P$. caninus, $P$. ornatus, $P$. otostegioides, $P$. montanus, and $P$. pseudomarrubioides were together in one group (Cluster F), while $P$. aegyptiacus, $P$. amboinicus, $P$. edulis, $P$. barbatus, and $P$. lanuginosus have been placed in another group (Cluster $G$ ).
The inner branches of the dendrogram show that $P$. caninus is similar to $P$. ornatus. $P$. otostegioides, $P$. montanus, and $P$. pseudomarrubioides are likewise similar, hence, they have been grouped together. $P$. aegyptiacus has also been placed close to $P$. amboinicus and, lastly, $P$. edulis, $P$. barbatus, and $P$. lanuginosus have been grouped together as well (Figure 6).

3.2.3. Dendrogram Based on Morphological Characters Described in the FTEA. Using gross morphological characters of the ten Plectranthus species previously described in Table 1, the following character state matrix (Table 5) was created and subjected to hierarchical cluster analysis.

Hierarchical cluster analysis of the above gross morphology character state matrix (Table 5) resulted in the following average linkage dendrogram (Figure 7). The dendrogram shows taxonomic relationships among the Plectranthus species based on gross morphological characters as described in FTEA [5].

Two main clusters/groups are evident from the dendrogram above which occur at about the same horizontal distance. One cluster $(\mathrm{H})$ contains $P$. lanuginosus, $P$. edulis, $P$. barbatus, $P$. caninus, $P$. otostegioides, and $P$. ornatus. The other cluster (I) contains P. montanus, $P$. amboinicus, $P$. pseudomarrubioides, and $P$. aegyptiacus. Cluster $\mathrm{H}$ further shows $P$. lanuginosus, $P$. edulis, and $P$. barbatus have been grouped together and $P$. caninus, $P$. otostegioides, and $P$. ornatus have been grouped together as well. This implies that members within each cluster are very close morphologically (Figure 7).

3.3. Discussion. Based on the current study, the MatK and Rbcl genes from ten Plectranthus species have been sequenced and phylogenetic trees have been reconstructed from the sequences. Based on the MatK gene sequences, $P$. caninus, $P$. otostegioides, $P$. barbatus, and $P$. lanuginosus have been grouped together (Cluster A), while P. ornatus, P. pseudomarrubioides, and $P$. aegyptiacus have been grouped together in another group, Cluster B (Figure 1). Species grouped together imply that they share a close common ancestor. 


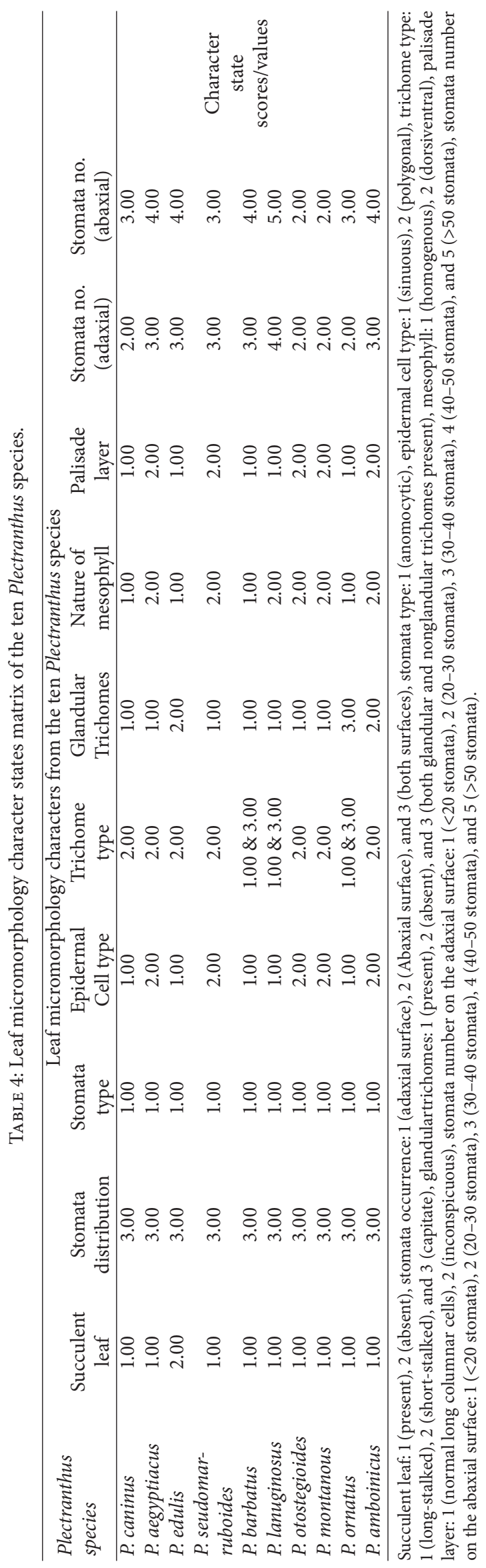




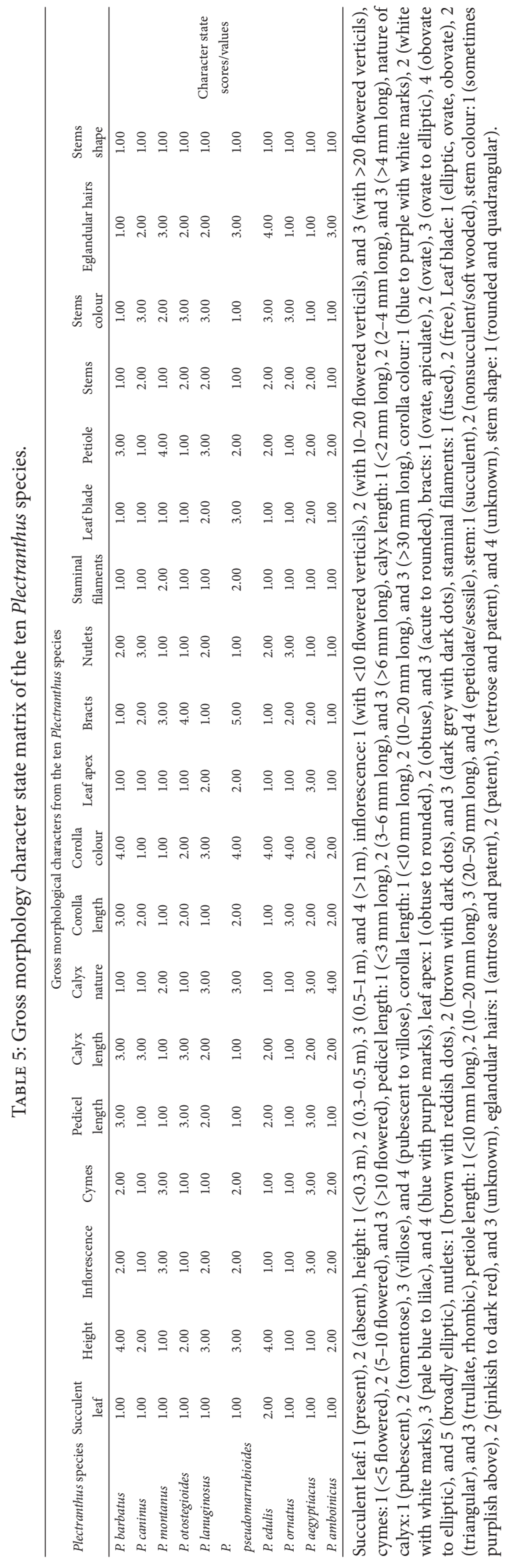




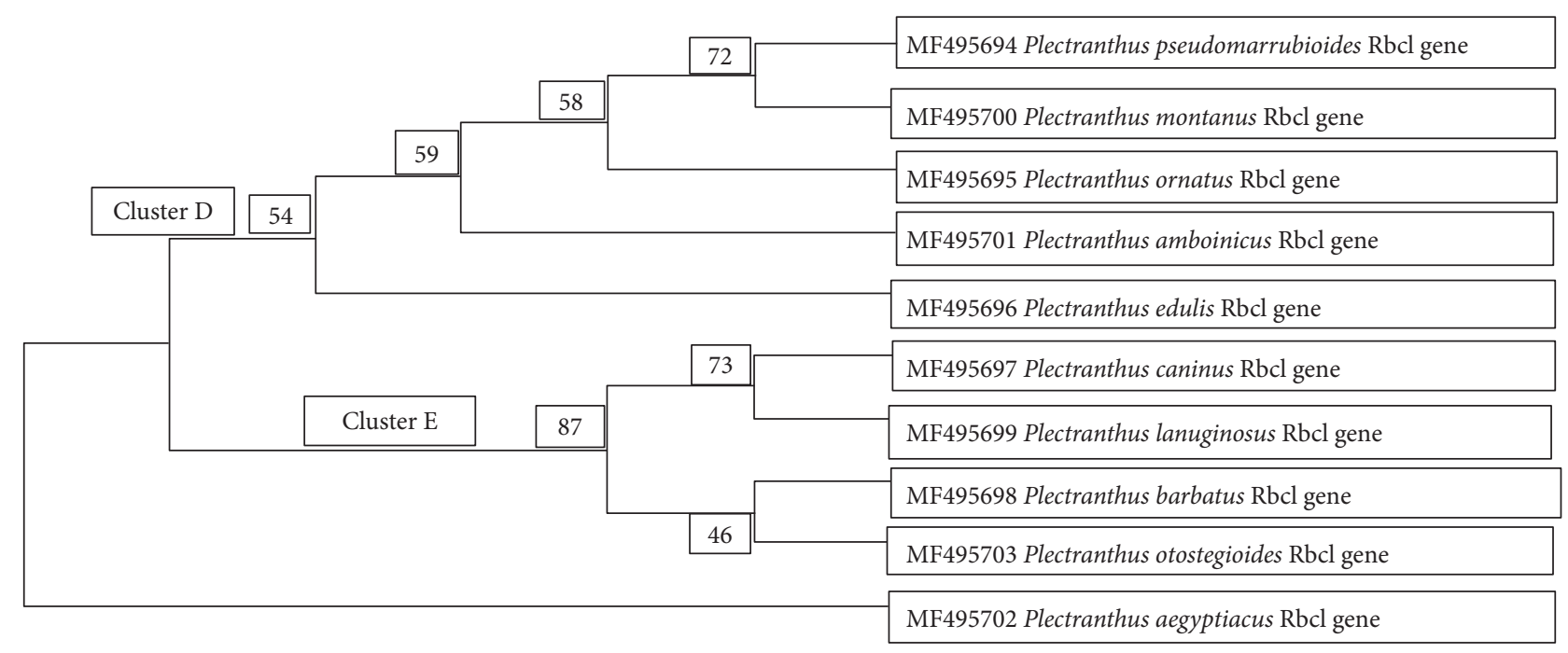

FIgURE 2: A bootstrap consensus phylogenetic tree based on $\mathrm{Rbcl}$ gene sequences.

The phylogenetic tree also shows that $P$ montanus and $P$. amboinicus form another group (Cluster C) and all the species share a distance common ancestor with $P$. edulis. On the other hand, a phylogenetic tree reconstructed based on the $\mathrm{Rbcl}$ gene sequences grouped together $P$. pseudomarrubioides, $P$. montanus, $P$. ornatus, P. amboinicus, and P. edulis (Cluster D), indicating that these four species are closely related (Figure 2). The $R b c l$ phylogenetic tree also grouped together $P$. caninus, $P$. lanuginosus, $P$. barbatus, and $P$. otostegioides forming another group (Cluster E), also indicating that both groups are related to $P$. aegyptiacus which is grouped alone. From the results, it may be argued that the MatK gene is better in delimiting $P$. aegyptiacus and, likewise, the $R b c l$ gene is better in delimiting $P$. edulis among species within the Coleus clade.

Comparison of the two trees based on the MatK and the $\mathrm{Rbcl}$ analyses shows that they are very similar. For example based on the MatK genes, $P$. caninus, $P$. otostegioides, $P$. barbatus, and $P$. lanuginosus have been grouped together. The same pattern can be observed in the phylogenetic tree created using the Rbcl genes implying that Cluster A based on the $M a t K$ genes is similar to Cluster E based on the $R b c l$ genes. Again based on the MatK genes, $P$. pseudomarrubioides, $P$. ornatus, $P$. montanus, and $P$. amboinicus have been shown to be closely related. This close relationship of these species can also be observed in phylogenetic tree produced using the $\mathrm{Rbcl}$ genes which likewise implies that Cluster B based on the MatK genes is similar to Cluster D based on the $\mathrm{Rbcl}$ genes. Based on the MatK genes, $P$. aegyptiacus was shown to be closely related to $P$. pseudomarrubioides and $P$. ornatus, while based on the $R b c l$ genes, $P$. edulis is closely related to $P$. amboinicus, $P$. ornatus, $P$. pseudomarrubioides, $P$. amboinicus, and P. montanus. Generally species grouped together in phylogenetic trees imply that they share a more recent ancestor.

Plectranthus species have been classified based on their ethnobotanical uses by Lukhoba et al. [2]. In that study, the authors were able to assign all the Plectranthus species in this study to the Coleus clade. Further, P. montanus was grouped together with $P$. pseudomarrubioides, $P$. amboinicus was grouped together with $P$. aegyptiacus, while $P$. barbatus, $P$. caninus, and $P$. lanuginosus were grouped together [2]. Their findings are similar to the observation in this study based on the MatK and $R b c l$ gene sequences. P. montanus and $P$. pseudomarrubioides have been shown to be closely related and $P$. barbatus, $P$. caninus, and $P$. lanuginosus have been shown to be closely related as well and hence have been grouped together.

$P$. amboinicus grouped together with $P$. montanus was shown to be distantly related to $P$. barbatus based on phylogenetic trees reconstructed from three plastid DNA gene sequences: $t r n L$ intron, $t r n L-t r n F$ intergene spacer, and $r p s 16$ gene by Paton et al. [4]. In addition, Al-Qurainy et al. [6] likewise observed that $P$. amboinicus was closely related to $P$. montanus. Such findings are supported by the results in the current study where by $M a t K$ and $R b c l$ phylogenetic trees showed that $P$. amboinicus was closely related to $P$. montanus, but distantly related to P. barbatus. In addition, the phylogenetic tree reconstructed by Al-Qurainy et al. [6] based on nrITS gene also indicated that $P$. barbatus was closely related to $P$. caninus. The findings by Paton et al. [4] and AlQurainy et al. [6] are in line with the data in the current study based on the MatK and $R b c l$ which have grouped together $P$. amboinicus and $P$. montanus and also grouped together $P$. barbatus and $P$. caninus, implying that these pairs of species are closely related.

A dendrogram produced from the cluster analysis of morphological characters described in the Flora of Tropical East Africa (Figure 7) showed two main groups: Cluster $\mathrm{H}$ and Cluster I. Cluster H contained the species P. lanuginosus, $P$. edulis, $P$. barbatus, $P$. caninus, $P$. otostegioides, and $P$. ornatus, while Cluster I contained P. montanus, $P$. amboinicus, $P$. pseudomarrubioides, and $P$. aegyptiacus. Inner branches of Cluster $\mathrm{H}$ further showed that $P$. lanuginosus, $P$. edulis, and $P$. barbatus were morphologically similar and $P$. caninus, $P$. otostegioides, and P. ornatus are morphologically similar as well hence they have been grouped together. Morphological 


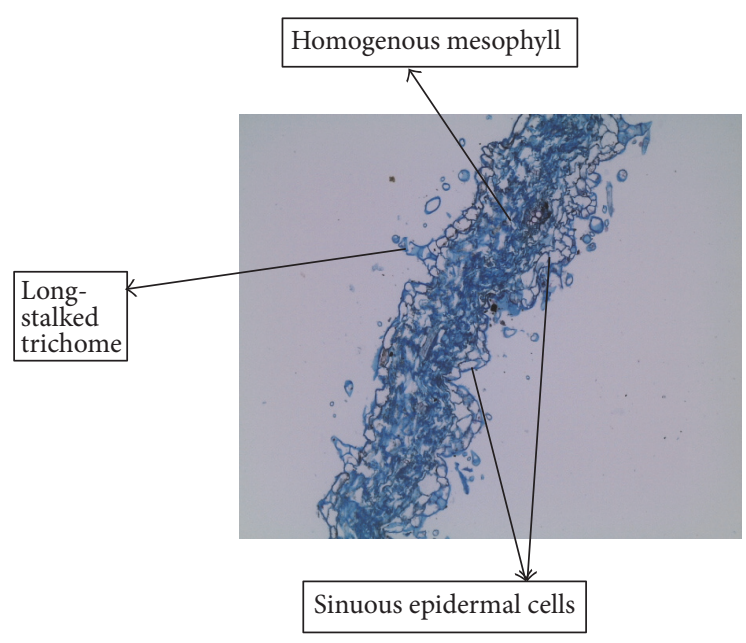

(a)

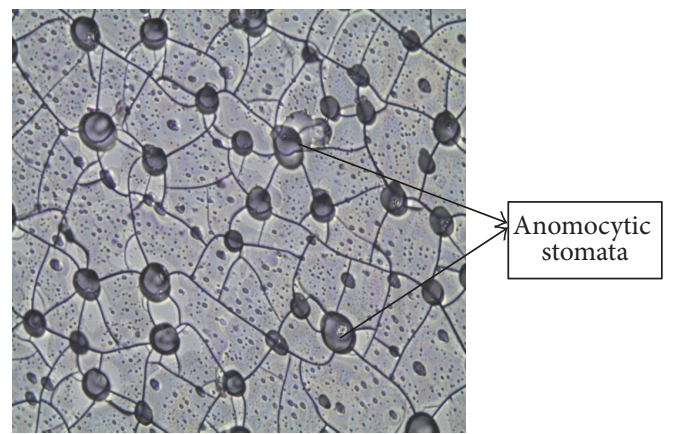

(b)

Figure 3: (a) Transverse section of $P$. lanuginosus leaf $(\mathrm{mg}=\times 100)$ showing homogenous mesophyll, sinuous epidermal cells, and long-stalked trichomes. (b) Abaxial surface of $P$. pseudomarrubioides leaf $(\mathrm{mg}=\times 400)$ showing anomocytic stomata.

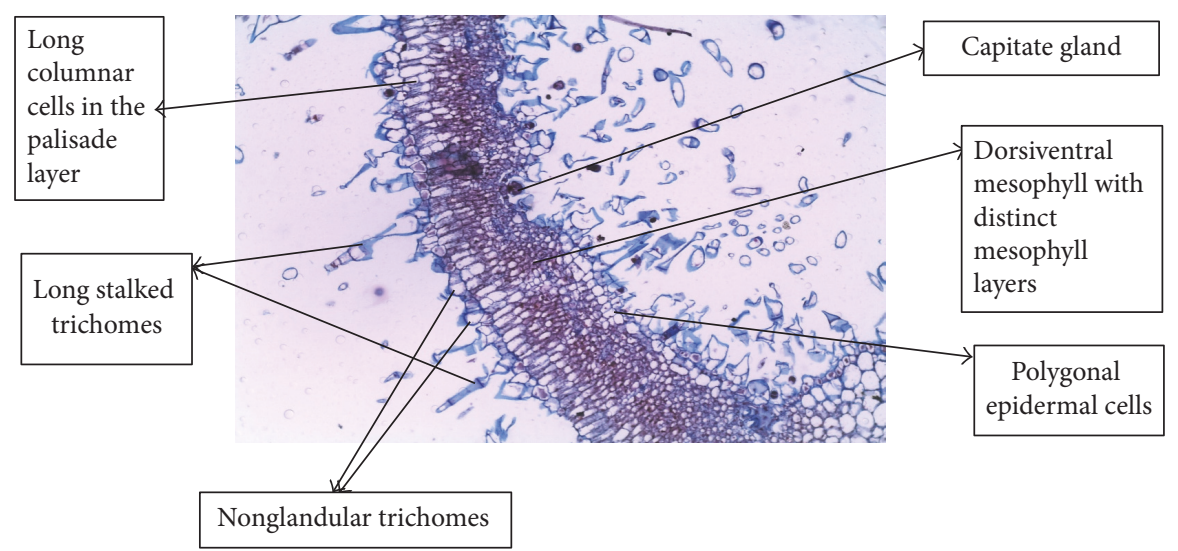

FIgURE 4: Transverse section of $P$. ornatus leaf. This pattern in $P$. ornatus of long columnar cells, long-stalked trichomes, dorsiventral mesophyll, and polygonal epidermal cells was also observed in P. edulis, P. barbatus, and P. caninus.

similarity in most cases is correlated to genetic similarity [34]. Hence, these close relations based on morphology within each group implied that members within each group were closely related. Such relationships of Plectranthus species described in the FTEA were very similar to what has been observed from the phylogenetic trees created from the MatK and $R b c l$ gene sequences in the current study.

Grayer investigated the distribution of exudate flavonoids in Plectranthus species and consequently came up with a phylogenetic tree based on the distribution of the exudate flavonoids [3]. Of particular interest to the current study are $P$. aegyptiacus, $P$. pseudomarrubioides, and $P$. montanus which are among the Plectranthus species Grayer investigated [3]. The study reported that both $P$. pseudomarrubioides and $P$. montanus produce Quercetin 3-methyl ether and Quercetin 3,7-dimethyl ether and also reported that both P. pseudomarrubioides and $P$. aegyptiacus produced Cirsimaritin [3]. This implies that $P$. pseudomarrubioides is genetically similar to both $P$. aegyptiacus and $P$. montanus and this supports the findings of the current study.

Leaf micromorphology in the present study involved investigation of the internal leaf anatomy and stomatal distribution of the ten Plectranthus species in the Coleus clade. Such a study focused on the arrangement of the leaf mesophylls, type of epidermal cells, trichomes, stomata density, stomata type, and stomata occurrence on both the abaxial and adaxial surfaces of the leaves. Data obtained from the study was used to generate average linkage dendrogram for better understanding of the taxonomic relationships between the ten species. Leaf anatomical characters which contributed to most of the differences in the ten Plectranthus investigated included epidermal cell type which was sinuous or polygonal (Figures 3 and 4), trichome type which ranged from being long-stalked, short-stalked, glandular, and nonglandular to capitate (Figure 5), the nature of the leaf mesophyll which was either homogenous or dorsiventral, 

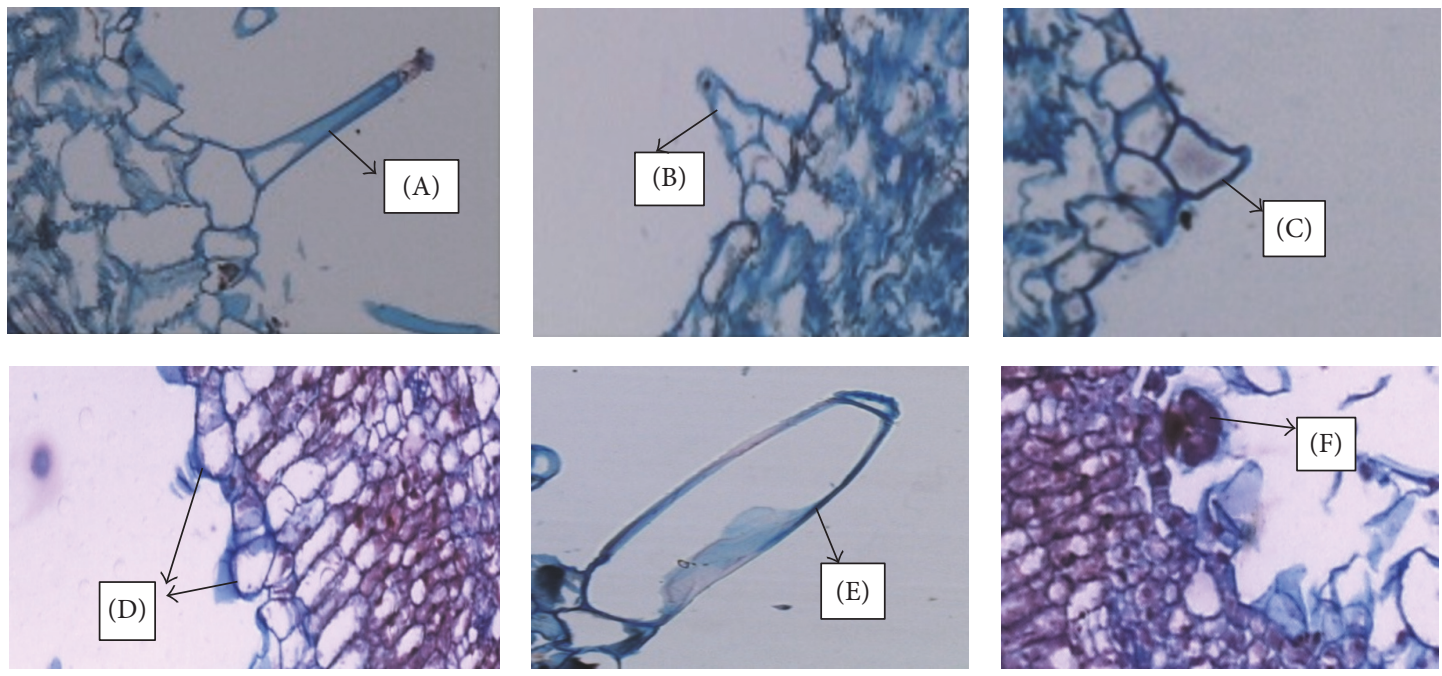

Figure 5: Trichomes identified in Plectranthus species: (A) long-stalked glandular trichome (in P. caninus and P. ornatus), (B) short-stalked glandular trichome (in P. aegyptiacus, P. edulis, P. pseudomarrubioides, P. otostegioides, P. montanus, and P. amboinicus), (C) capitate nonstalked trichome (in P. ornatus), (D) nonglandular trichomes (in P. ornatus), (E) capitate glandular trichome (in P. lanuginosus and P. barbatus), and (F) capitate glands (in P. ornatus).

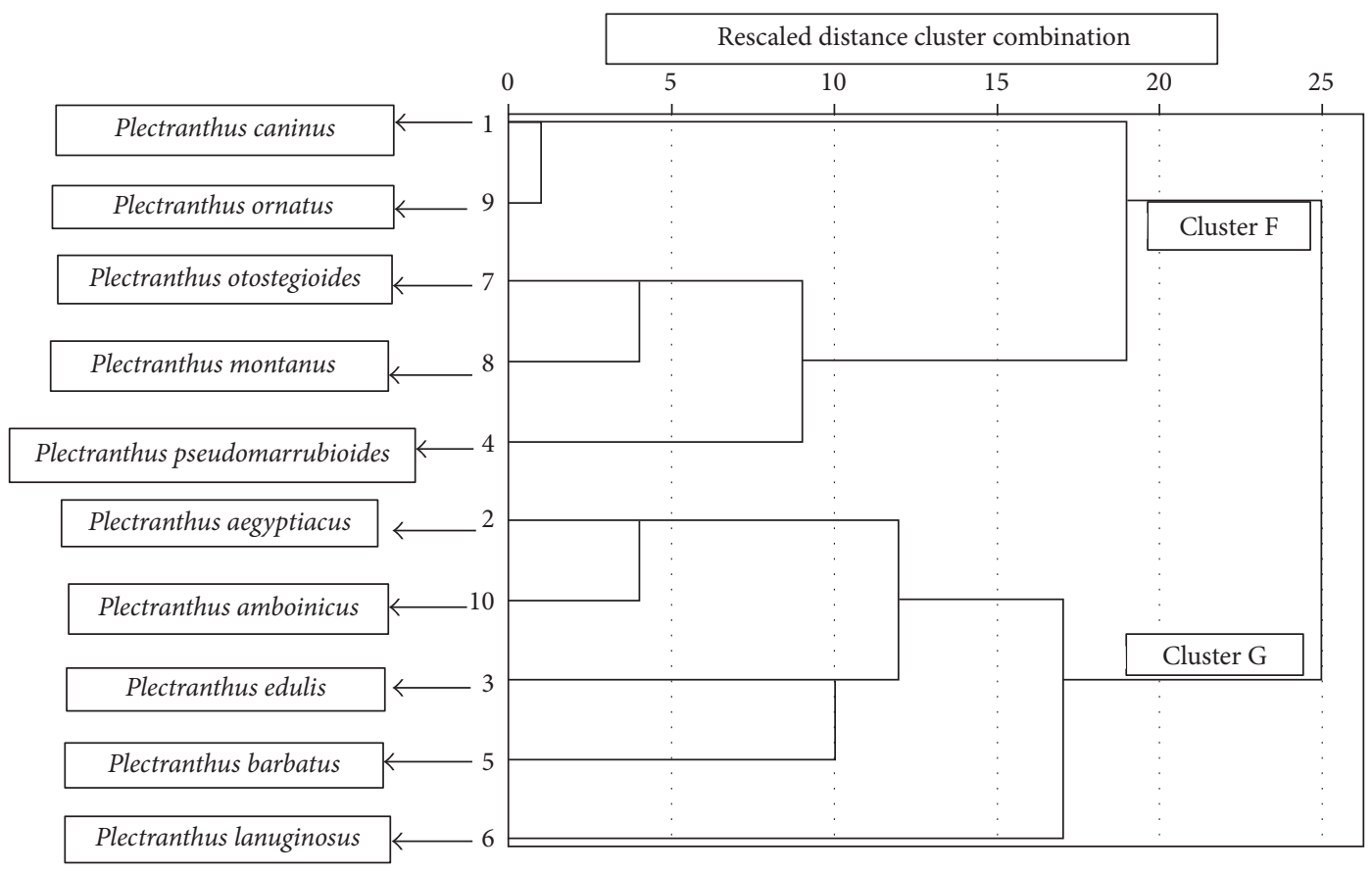

FIGURE 6: Leaf micromorphology average linkage dendrogram.

and the nature of the palisade layer (Figures 3 and 4). From the leaf micromorphology dendrogram (Figure 6), the ten Plectranthus species were grouped into two main groups: $P$ caninus, $P$ ornatus, $P$ otostegioides, $P$. montanus, and $P$. pseudomarrubioides were grouped together in Cluster $\mathrm{F}$, while $P$. aegyptiacus, $P$. amboinicus, $P$. edulis, $P$. barbatus, and $P$. lanuginosus were placed in Cluster $G$. The inner branches of Cluster $\mathrm{F}$ show that $P$. caninus is similar to P. ornatus. In addition, by looking at Cluster F, $P$. otostegioides, $P$. montanus, and $P$. pseudomarrubioides were found to be morphologically similar. $P$. aegyptiacus was also placed close to $P$. amboinicus and, lastly, $P$. edulis, $P$. barbatus, and $P$. lanuginosus were grouped together as well as seen in Cluster G.

Epidermal cell type, type of stomata, type of trichome, and the nature of the mesophyll have been used before to differentiate $P$. barbatus and $P$. neochilus from other South American Labiatae species referred by the same common name [14]. P. barbatus was reported to possess anomocytic stomata, 


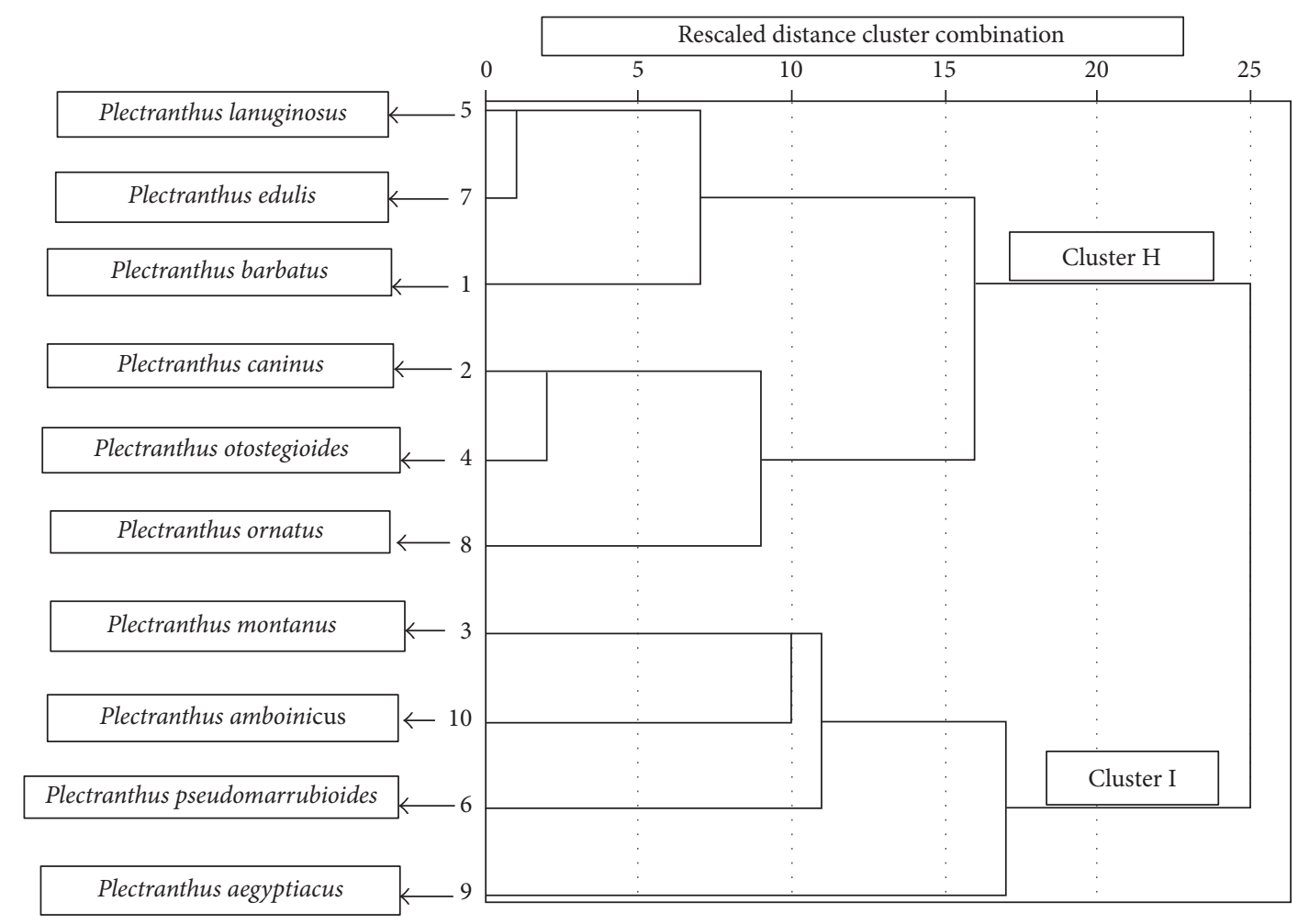

Figure 7: Average linkage dendrogram showing taxonomic relationships of the ten Plectranthus species based on morphological characters in the FTEA.

dorsiventral mesophyll, capitate glandular trichomes, and polygonal epidermal cells [14]. Such findings on leaf anatomical characters of $P$. barbatus have been supported by the results of the current study. Four types of glandular trichomes of taxonomic significance on the abaxial surface of leaves have been reported in various developmental stages of $P$. ornatus. These include long-stalked capitate trichomes, short-stalked capitate trichome, and digitiform and conoidal trichomes [18] and this supports the current study whereby $P$. ornatus was found to possess long-stalked glandular trichomes.

$P$. montanus and P. pseudomarrubioides have been reported to have short-stalked peltate trichomes [35] and this likewise corroborates the current leaf micromorphology study where the two species have been reported to have short-stalked trichomes. P. amboinicus was reported to have rectangular to polygonal leaf epidermal cells with more glandular than nonglandular trichomes on both the adaxial and abaxial leaf surfaces [36]. In addition, the leaf mesophyll of $P$. amboinicus was also described to be homogenous consisting of undifferentiated compact square-like cells [36]. These results of leaf micromorphology of $P$. amboinicus were in agreement with the results obtained in the current study whereby $P$. amboinicus was reported to have homogenous mesophyll and short-stalked trichomes. Generally, isobilateral, centric, or dorsiventral leaf mesophyll has been reported in species within the Lamiaceae family [16].

Organisms grouped together in a dendrogram imply that they are more similar morphologically. In most cases similarity based on morphology is related to genetic similarity because traits are determined by genes and a similar character in different plants strongly suggests that there is a shared gene by those species possessing the morphological character. Hence, it can be assumed that, the more close the species are grouped, the more recently they diverged from a common ancestor. Morphological characters are often affected by environmental factors and morphological variation seen in species can either be environmentally induced or genetically based [37]. The same species growing in different ecological zones can display varied morphological characters. For example, by referring to the leaf micromorphology dendrogram, Cluster $\mathrm{F}$ shows that $P$. otostegioides, $P$. montanus, and $P$. pseudomarrubioides have been grouped together and P. edulis, $P$. barbatus, and $P$. lanuginosus have been grouped together as well in Cluster G. Such a grouping based on character can similarly be attributed to environmental influence on the species growing in their habitats. P. otostegioides, P. montanus, and $P$. pseudomarrubioides were collected in dry regions of Kenya which were Olorgesailie, Makueni, and Naivasha. respectively, while $P$. edulis, $P$. barbatus, and $P$. lanuginosus were collected from wet regions in Kenya which were Transnzoia, Nairobi, and Nairobi, respectively. This may strongly suggest that the environment might have influenced their stomata density and other leaf micromorphology characters making the species possess near similar characters hence after the cluster analysis they were grouped together.

As mentioned before, a dendrogram produced from cluster analysis of gross morphological characters described in the Flora of Tropical East Africa (Figure 7) groups the 
ten Plectranthus species into two main groups: Cluster $\mathrm{H}$ and Cluster I. By comparing the gross morphological dendrogram (Cluster $\mathrm{H}$ and $\mathrm{I}$ ) with the leaf micromorphology dendrogram (Cluster F and G), some similarities between the two can be deduced. For instance, $P$. lanuginosus, $P$. edulis, and $P$. barbatus have been grouped together by the two dendrograms (Cluster $\mathrm{G}$ and $\mathrm{H}$ ). Similarly P. montanus and $P$. pseudomarrubioides have been grouped together in the two dendrograms (Cluster F and I). One major similarity between the leaf micromorphology dendrogram and the molecular phylogenetic trees include placement of $P$. barbatus and $P$. lanuginosus in the same group. Other species which have been placed in the same group by both the leaf micromorphology dendrogram and the molecular phylogenetic trees are $P$. pseudomarrubioides, $P$. montanous, and $P$. ornatus. This clearly shows that the obtained leaf micromorphology data is supported by molecular data from the MatK and $R b c l$ sequences. This strongly implies that $P$. barbatus and $P$. lanuginosus are closely related and the same conclusion of close relatedness can be made on $P$. pseudomarrubioides, $P$. montanus, and P. ornatus.

Findings of the leaf micromorphology study have been supported by previous classification based on their ethnobotanical uses where most of the species belonging to Coleus clade were grouped together by Lukhoba et al. [2]. P. montanus was placed in the same group with $P$. pseudomarrubioides, $P$. amboinicus was placed together with P. aegyptiacus, while $P$. barbatus, $P$. caninus, and $P$. lanuginosus were grouped together as well [2]. A study carried out by Khalik using ultrastructure characters of pollen grains and trichomes to classify Saudi Arabian Plectranthus species showed that $P$. montanus and $P$. pseudomarrubioides were closely related to each other [35] and this agrees with the current study whereby the two species have been grouped together.

Morphological characters have been employed widely in the identification and classification of plants. In closely related species, these morphological characters may differ by a small margin and it may not be easy to identify and classify closely related species. Studies on leaf micromorphology are important sources of taxonomic characters for classification of plants which are difficult to delimit. Some of these characters are of diagnostic value and have been used successfully in infrageneric and interspecific classification in plants. Most morphological characters overlap when we look at species at the lower taxonomic ranks especially in genus and subgenus levels making it hard to classify species based on the general morphological characters. As a result diagnostic morphological characters are vital when it comes to morphology based phylogenetic studies. Micromorphological characters are examples of such diagnostic characters which have proved vital in the delimitation of species below the genus level $[38,39]$.

Based on the current leaf micromorphology study epidermal cell type, type and nature of trichomes, mesophyll type, and palisade layer have proved to be vital diagnostic characters for differentiating the ten species investigated, while characters such as the presence or absence of a succulent leaf, type of stomata, number of stomata, and occurrence of stomata have been shown to be less important in differentiating the ten species. Dendrogram produced from the leaf micromorphology characters classifies the ten Plectranthus species in a pattern which has been supported by previous researchers. Hence, the current study has proved that studies of leaf micromorphology can aid in determination of diagnostic morphological characters which can aid in plant delimitation and phylogenetic studies.

With regard to molecular phylogeny, phylogenetic trees reconstructed based on the MatK and the $R b c l$ gene sequences have showed phylogenetic relationships among the ten Plectranthus species and proved that the species are actually monophyletic in origin. Furthermore, the results obtained were in congruent with results obtained by previous researchers on phylogeny of the Plectranthus genus as far as the ten species are concerned. The study proved that molecular characters are indeed valuable in phylogenetic studies especially in the lower taxonomic ranks whereby morphological characters may not delimit species successfully.

\section{Conclusions}

Plectranthus species are difficult to distinguish morphologically and specific species have been given different names by different authors instead of one legitimate name. Use of morphological characters is not sufficiently enough to delimit the genus successfully. Molecular, anatomical, and biochemical markers are valuable when studying interspecific variation compared to gross morphological markers. By comparing the same gene sequence across species within a genus, a phylogenetic tree can be constructed which can support or give new insights into the existing classification and rule out the confusion brought by synonymy. From the results, a phylogenetic tree reconstructed using the MatK genes grouped $P$. caninus, $P$. otostegioides, $P$. barbatus, and $P$. lanuginosus together (Cluster A). Again based on the MatK genes, $P$. pseudomarrubioides, $P$. ornatus, $P$. montanus, and $P$. amboinicus were shown to be closely related and hence grouped together in Clusters B and C. Still based on the MatK phylogenetic tree, the aforementioned species were shown to share a distant common ancestor with $P$. edulis. The same trend was observed in the phylogenetic tree created using the $\mathrm{Rbcl}$ genes sequences (Cluster D and E), although the $\mathrm{Rbcl}$ phylogenetic tree grouped $P$. edulis close to $P$. amboinicus and showed $P$. aegyptiacus to be distantly related to the other nine species despite being grouped close to $P$. pseudomarrubioides and $P$. ornatus by the MatK phylogenetic tree.

From the leaf micromorphology study, $P$. caninus, $P$. ornatus, $P$. otostegioides, $P$. montanus, and P. pseudomarrubioides are closely related (Cluster F), while P. aegyptiacus, $P$. amboinicus, $P$. edulis, $P$. barbatus, and $P$. lanuginosus are closely related as well (Cluster G). Furthermore, the leaf micromorphology study showed that $P$. caninus is closely related to $P$. ornatus, while $P$. otostegioides, $P$. montanus, and $P$. pseudomarrubioides have been shown to be related as well. $P$. aegyptiacus has been placed close to $P$. amboinicus and lastly P. edulis, P. barbatus, and P. lanuginosus have been grouped together as well. The findings from the study have been supported by findings from previous morphological, biochemical, and molecular studies which have reported that 
Plectranthus species are closely related. It can be concluded that, studies of leaf micromorphology can aid in the determination of diagnostic morphological characters which can aid in plant identification and phylogenetic studies.

Analysis of morphological data through cluster analysis groups species together based on their overall similarity and this grouping can be presented in form of cladograms, dendrograms, or even phylogenetic trees. Morphological characters have various shortcomings especially when used to delimit species at the genus level. Most of these characters overlap and it's hard to identify the diagnostic characters which can be used to differentiate one species from the rest. It has been argued that the most suitable method for classifying species based on morphological data has not yet been decided and different methods applied on the same data can result in different classifications [38]. However, analysis of morphological data can prove valuable when placing a new species within a higher taxonomic rank [40].

Although molecular and biochemical data have many advantages and their increase is being used in systematic studies, it is important that morphological systematics should not be entirely abandoned because they can aid in the classification of poorly known groups as well as study of fossil data [41]. The first process of identifying a collected plant species is describing it by listing its morphological characters. Hence, if plant taxonomists focus entirely on molecular and biochemical techniques, then they might not be able to identify new species and research on unidentified species may come to a halt. Correct identification of species in the field and in the herbarium is based on the species morphological data [42].

Further research involving more Plectranthus species within the Coleus and Plectranthus clade should be conducted to better understand their taxonomic relationships. Roughly one hundred Plectranthus are found in East Africa; about seventy of the species belong to the Coleus clade and about thirty of them belong to the Plectranthus clade. Investigations on molecular phylogeny of all the species will help researchers in dealing with the problems of synonymy and place Plectranthus species in their right positions. Such studies will not only involve the use of the MatK and the Rbcl genes but it can also involve the use of other molecular markers and methods which have been used successfully in phylogenetic studies of angiosperms such as ndh-F, atpB, trnT-trnL, trnL-trnF, and atpB-Rbcl. A comparison of phylogenetic trees based on two or three gene sequences can prove valuable in systematics.

Morphological characters are affected by environmental factors and the same morphological character within the same species can be pronounced or decreased depending on the ecological zone where the species is thriving. Hence, it is very important for one to establish whether differences among species observed from morphological characters are due to actual genetic differences or environmental factors. Species classification using morphological data is usually based on diagnostic characters rather than phylogenetic analysis and the classification produced may not give the correct evolutionary relationships of the species involved. For one to make accurate phylogenetic inferences from morphological data dendrograms, it is important to compare such dendrograms with phylogenetic trees based on molecular or biochemical data.

\section{Disclosure}

An earlier version of this research work was presented in XXI AETFAT Congress: Systematics, biogeography and Conservation of African plants and fungi, held at the Catholic University of Eastern Africa, May 2017 [43].

\section{Conflicts of Interest}

The authors have not declared any conflicts of interest.

\section{Acknowledgments}

The authors are very grateful to the University of Nairobi and the German Academic Exchange Service (DAAD) for funding the above study.

\section{References}

[1] L. J. Rice, G. J. Brits, C. J. Potgieter, and J. Van Staden, "Plectranthus: a plant for the future?" South African Journal of Botany, vol. 77, no. 4, pp. 947-959, 2011.

[2] C. W. Lukhoba, M. S. J. Simmonds, and A. J. Paton, "Plectranthus: a review of ethnobotanical uses," Journal of Ethnopharmacology, vol. 103, no. 1, pp. 1-24, 2006.

[3] R. J. Grayer, M. R. Eckert, A. Lever, N. C. Veitch, G. C. Kite, and A. J. Paton, "Distribution of exudate flavonoids in the genus Plectranthus," Biochemical Systematics and Ecology, vol. 38, no. 3, pp. 335-341, 2010.

[4] A. J. Paton, D. Springate, S. Suddee et al., "Phylogeny and evolution of basils and allies (Ocimeae, Labiatae) based on three plastid DNA regions," Molecular Phylogenetics and Evolution, vol. 31, no. 1, pp. 277-299, 2004.

[5] A. J. Paton, G. Bramley, O. Rying et al., Flora of Tropical East Africa Lamiaceae (Labaiate), Royal Botanical Gardens, Kew, 2009.

[6] F. Al-Qurainy, S. Khan, M. Nadeem, M. Tarroum, and A. AlAmeri, "Selection of DNA barcoding loci and phylogenetic study of a medicinal and endemic plant, Plectranthus asirensis J.R.I. wood from Saudi Arabia," Genetics and Molecular Research, vol. 13, no. 3, pp. 6184-6190, 2014.

[7] J. D. M. Bandeira, V. J. Bianchi, S. Rubin, J. A. Peters, and E. J. B. Braga, "Genetic similarities among four species of the Plectranthus (L'Hér.) genus," Acta Scientiarum - Biological Sciences, vol. 32, no. 1, pp. 43-48, 2010.

[8] A. P. P. R. Amarasinghe, D. A. S. Siriwardhane, R. R. Samarasekera, and O. V. D. S. J. Weerasena, "Development of DNA barcodes and optimization of DNA isolation and PCR Protocols for a medicinal plant Plectranthus hadiensis," International Journal of Science and Research, vol. 4, no. 6, pp. 2852-2856, 2013.

[9] H.-K. Moon, S.-P. Hong, E. Smets, and S. Huysmans, "Phylogenetic significance of leaf micromorphology and anatomy in the tribe Mentheae (Nepetoideae: Lamiaceae)," Botanical Journal of the Linnean Society, vol. 160, no. 2, pp. 211-231, 2009.

[10] A. Bisio, A. Corallo, P. Gastaldo et al., "Glandular hairs and secreted material in Salvia blepharophylla Brandegee ex Epling grown in Italy," Annals of Botany, vol. 83, no. 4, pp. 441-452, 1999. 
[11] G. Corsi and S. Bottega, "Glandular hairs of Salvia officinalis: new data on morphology, localization and histochemistry in relation to function," Annals of Botany, vol. 84, no. 5, pp. 657664, 1999.

[12] R. F. Evert, Esau's Plant Anatomy: Meristems, Cells, and Tissues of The Plant Body: Their Structure, Function, and Development, John Wiley \& Sons, 2006.

[13] A. Cronquist, An Integrated System of Classification of Flowering Plants, Columbia University Press, 1981.

[14] M. F. Duarte and J. F. Lopes, "Stem and leaf anatomy of Plectranthus neochilus Schltr., Lamiaceae," Revista Brasileira de Farmacognosia, vol. 17, no. 4, pp. 549-556, 2007.

[15] C. R. Metcalfe and L. Chalk, Anatomy of The Dicotyledons, Oxford: Clarendon Press, Oxford, UK, 2nd edition, 1988.

[16] F. E. Fritsch, Anatomy of the Dicotyledons. Leaves, Stem and Wood in Relation to Taxonomy, with Notes on Economic Uses. Vols. I and II, Oxford at the Clarendon Press, 1950.

[17] E. Werker, "Function of essential oil-secreting glandular hairs in aromatic plans of Lamiacea-a review," Flavour and Fragrance Journal, vol. 8, no. 5, pp. 249-255, 1993.

[18] L. Ascensão, L. Mota, and M. D. M. Castro, "Glandular trichomes on the leaves and flowers of Plectranthus ornatus: morphology, distribution and histochemistry," Annals of Botany, vol. 84, no. 4, pp. 437-447, 1999.

[19] K. N. A. Khalik and E. A. Karakish, "Comparative anatomy of stems and leaves of plectranthus L. (Lamiaceae) in Saudi Arabia and systematic implications," Microscopy Research and Technique, vol. 79, no. 7, pp. 583-594, 2016.

[20] P. Catalán, Y. Shi, L. Armstrong, J. Draper, and C. A. Stace, "Molecular phylogeny of the grass genus Brachypodium P. Beauv. based on RFLP and RAPD analysis," Botanical Journal of the Linnean Society, vol. 117, no. 4, pp. 263-280, 1995.

[21] M. Abdulla and O. Gamal, "Investigation on molecular phylogeny of some date palm (Phoenix dactylifra L.) cultivars by protein, RAPD and ISSR markers in Saudi Arabia," Australian Journal of Crop Science, vol. 4, no. 1, pp. 23-28, 2010.

[22] M. Hajibabaei, G. A. C. Singer, P. D. N. Hebert, and D. A. Hickey, "DNA barcoding: how it complements taxonomy, molecular phylogenetics and population genetics," Trends in Genetics, vol. 23, no. 4, pp. 167-172, 2007.

[23] F. De Mattia, I. Bruni, A. Galimberti, F. Cattaneo, M. Casiraghi, and M. Labra, "A comparative study of different DNA barcoding markers for the identification of some members of Lamiacaea," Food Research International, vol. 44, no. 3, pp. 693-702, 2011.

[24] I. Bruni, A. Galimberti, L. Caridi et al., "A DNA barcoding approach to identify plant species in multiflower honey," Food Chemistry, vol. 170, pp. 308-315, 2015.

[25] M. Li, H. Cao, P. P. H. But, and P. C. Shaw, "Identification of herbal medicinal materials using DNA barcodes," Journal of Systematics and Evolution, vol. 49, no. 3, pp. 271-283, 2011.

[26] K. Tamura, G. Stecher, D. Peterson, A. Filipski, and S. Kumar, "MEGA6: Molecular Evolutionary Genetics Analysis version 6.0," Molecular Biology and Evolution, vol. 30, no. 12, pp. 27252729, 2013.

[27] R. C. Edgar, "MUSCLE: multiple sequence alignment with high accuracy and high throughput," Nucleic Acids Research, vol. 32, no. 5, pp. 1792-1797, 2004.

[28] P. H. A. Sneath and R. R. Sokal, Numerical Taxonomy: The Principles and Practice of Numerical Classification, W. H. Freeman, San Francisco, Calif, USA, 1973.
[29] B. Efron and R. J. Tibshirani, An Introduction to the Bootstrap, Monographs on Statistics and Applied Probability, Chapman and Hall, New York, NY, USA, 1993.

[30] A. P. Davis and J. R. Barnett, "The leaf anatomy of the genus Galanthus L. (Amaryllidaceae J. St.-Hill)," Botanical Journal of the Linnean Society, vol. 123, no. 4, pp. 333-352, 1997.

[31] M. G. Al-Saghir, D. M. Porter, and E. T. Nilsen, "Leaf anatomy of Pistacia species (Anacardiaceae)," Journal of Biological Sciences, vol. 6, no. 2, pp. 242-244, 2006.

[32] U. K. Abdel-Hameed, M. E. Tantawy, M. A. Salim, M. M. Mourad, and I. F. Ishak, "Phenetic Analysis of Morphological and Molecular Traits in Acanthaceae Juss," Journal of Biosciences and Medicines, vol. 3, no. 3, pp. 18-34, 2015.

[33] O. Yim and K. T. Ramdeen, "Hierarchical cluster analysis: comparison of three linkage measures and application to psychological data," The Quantitative Methods for Psychology, vol. 11, no. 1, pp. 8-21, 2015.

[34] L. D. Gottlieb, "Electrophoretic evidence and plant populations," Progress in Phytochemistry, vol. 7, no. 1, p. 46, 1981.

[35] K. N. Abdel Khalik, "A systematic revision of the genus Plectranthus L. (Lamiaceae) in Saudi Arabia based on morphological, palynological, and micromorphological characters," American Journal of Plant Sciences, vol. 7, no. 10, p. 1429, 2010.

[36] N. D. Kaliappan and P. K. Viswanathan, "Pharmacognostical studies on the leaves of Plectranthus amboinicus (Lour) Spreng," International Journal of Green Pharmacy, vol. 2, no. 3, pp. 182184, 2008.

[37] C. P. Klingenberg, "Evolution and development of shape: integrating quantitative approaches," Nature Reviews Genetics, vol. 11, no. 9, pp. 623-635, 2010.

[38] Y. Salmaki, S. Zarre, Z. Jamzad, and C. Bräuchler, “Trichome micromorphology of Iranian Stachys (Lamiaceae) with emphasis on its systematic implication," Flora, vol. 204, no. 5, pp. 371381, 2009.

[39] C.-L. Xiang, Z.-H. Dong, H. Peng, and Z.-W. Liu, “Trichome micromorphology of the East Asiatic genus Chelonopsis (Lamiaceae) and its systematic implications," Flora, vol. 205, no. 7, pp. 434-441, 2010.

[40] E. O. Wiley, Phylogenetics. The Principles and Practice of Phylogenetic Systematics, Wiley J \& Sons, New York, NY, USA, 1981.

[41] D. M. Hillis and J. J. Wiens, "Molecules versus morphology in systematics: conflicts, artifacts, and misconceptions," in Phylogenetic Analysis of Morphological Data, pp. 1-19, 2000.

[42] M. K. Krause, "Molecular approaches and the growth of phylogenetic biology," in Molecular Zoology: Advances, Strategies, and Protocols, J. D. Ferraris and S. R. Palumbi, Eds., pp. 47-63, Wiley-Liss, New York, NY, USA, 1996.

[43] F. M. Musila, C. W. Lukhoba, S. F. Dossaji, and J. M. Nguta, "Molecular Phylogeny of ten Kenyan Plectranthus species in the Coleus clade," in Proceedings of the XXI AETFAT congress, Catholic University of Eastern Africa, Nairobi, Kenya, 2017. 

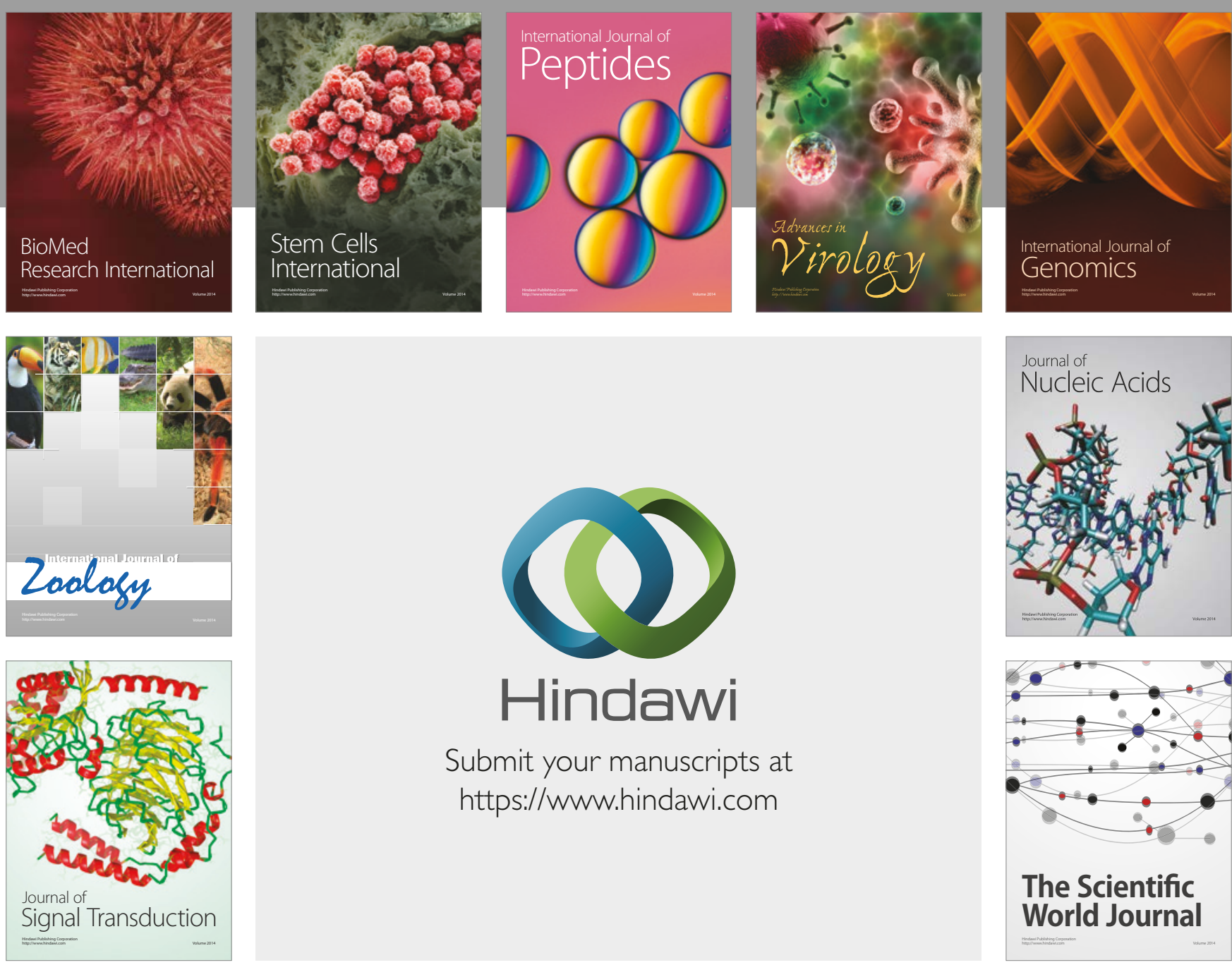

Submit your manuscripts at

https://www.hindawi.com
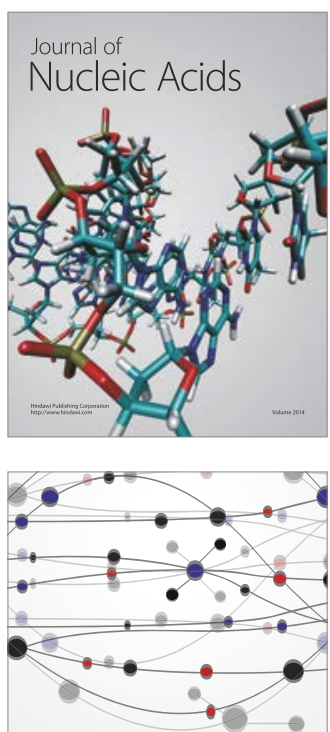

The Scientific World Journal

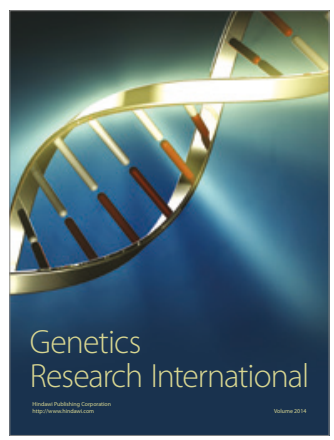

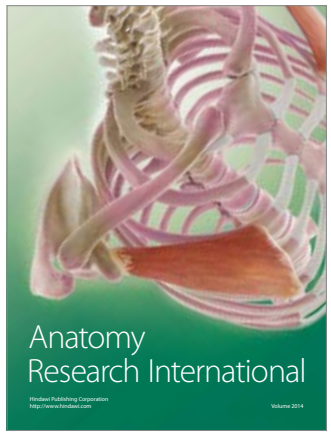

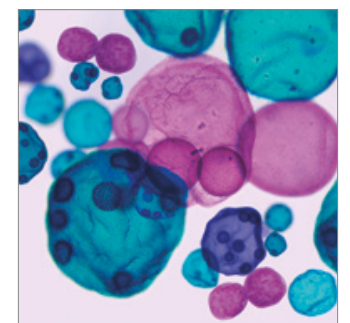

International Journal of Microbiology
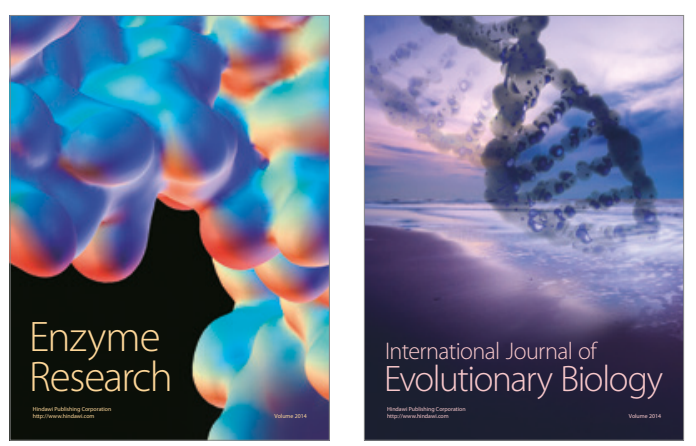
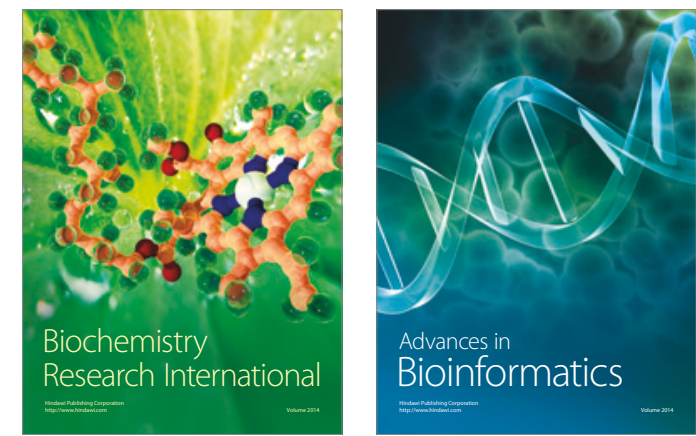

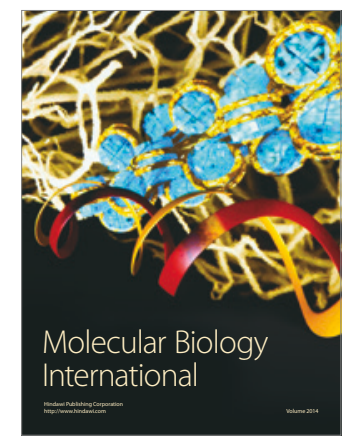

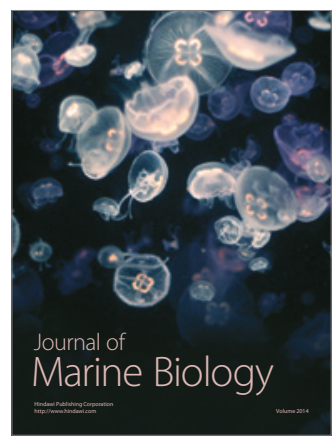

